\title{
Mountain Daylight Time
}

National Cancer Institute

\section{Source}

National Cancer Institute. Mountain Daylight Time. NCI Thesaurus. Code C116259.

Local daylight-savings time, based at the 105th meridian west of the Greenwich

Observatory, established as six hours behind Coordinated Universal T ime. 